Article

\title{
Detection of Cyanotoxin-Producing Genes in a Eutrophic Reservoir (Billings Reservoir, São Paulo, Brazil)
}

\author{
Matheus S. F. Ribeiro ${ }^{1,2}$, Andrea Tucci ${ }^{3}$, Matheus P. Matarazzo ${ }^{2}$, Cristina Viana-Niero ${ }^{1, *}$ and \\ Cristina S. F. Nordi ${ }^{2}$ \\ 1 Departamento de Microbiologia, Imunologia e Parasitologia, Universidade Federal de São Paulo, \\ Rua Botucatu, 862, São Paulo 04023-901, Brazil \\ 2 Departamento de Ciências Ambientais, Universidade Federal de São Paulo, Rua Prof. Artur Riedel, 275, \\ Diadema 09972-270, Brazil \\ 3 Centro de Pesquisa em Plantas Avasculares e Fungos, Núcleo de Pesquisa em Ficologia, \\ Instituto de Botânica, Av. Miguel Estéfano, 3687, São Paulo 04301-012, Brazil \\ * Correspondence: cristina.viana@unifesp.br; Tel.: +55-(11)-55764848
}

Received: 2 October 2019; Accepted: 13 December 2019; Published: 23 March 2020

\begin{abstract}
CyanoHABs (cyanobacterial harmful algal blooms) are blooms of cyanobacteria capable of producing cyanotoxins, a large group of secondary metabolites that are toxic to most eukaryotes. In this work, the main aim was to evaluate the presence of multiple genes from each of the clusters responsible for biosynthesis of cyanotoxins (cylindrospermopsin, microcystin and saxitoxin) in total DNA obtained from sixteen environmental water samples by PCR. Microcystin gene $m c y E$ was amplified in all analyzed samples. Among the cylindrospermopsin genes analyzed, only the cyrC gene was amplified from DNA obtained from three of sixteen samples. Of the three different saxitoxin genes analyzed, $s x t B$ and $s x t I$ were present in four and three of the sixteen samples studied, respectively, and $s x t A$ did not show any positive result. Based on our results, we suggest caution when using only one gene from the full clusters responsible for biosynthesis of cyanotoxins, given that it may not be sufficient to confirm or exclude the toxigenic potential of a sample.
\end{abstract}

Keywords: cyanotoxin genes; environmental monitoring; PCR

\section{Introduction}

Cyanobacteria are recognized as the most widespread photosynthetic organisms mainly because they show a cosmopolitan distribution and prominent ecological occupation in eutrophic environments, with the tendency to produce blooms [1,2]. Cyanobacterial blooms are considered harmful to aquatic environment because they can alter a wide range of ecosystem factors such as oxygen levels, $\mathrm{pH}$ and light availability. Most of the bloom-forming species are capable of producing cyanotoxins and are called cyanobacterial harmful algal blooms (CyanoHABs) [2-5].

Cyanotoxins are large groups of secondary metabolites which are toxic to most eukaryotic organisms and can be classified according to their mechanism of action: neurotoxic (anatoxin-a and analogues, saxitoxin and analogues), hepatotoxic (microcystins and nodularins), dermatotoxic (lipopolysaccharides) and cytotoxic (cylindrospermopsins) [6-8]. Some species and genera, such as Microcystis aeruginosa, Raphidiopsis raciborskii (Woloszynska) Aguilera, Berrendero Gómez, Kastovsky, Echenique and Salerno (basionym Cylindrospermopsis raciborskii (Woloszynska) Seenayya and Subba Raju) [9], Planktothrix and Dolichospermum have been numerously reported to produce toxins [7,10-12].

Monitoring cyanobacteria and cyanotoxins is of utmost importance in water bodies used for public water supply due to the characteristics described above. Thus, several countries have regulations for 
water body certification, which establish limits on the number of cyanobacterial cells and cyanotoxins levels. Cyanobacteria monitoring is carried out mainly by cell counts and is expressed in cells per $\mathrm{mL}$ or biovolume. The World Health Organization (WHO) suggests investigating biovolume values above $0.2 \mathrm{~mm}^{3} / \mathrm{L}$ [13]. Brazilian regulations allow cyanobacterial biovolumes of up to $10.0 \mathrm{~mm}^{3} / \mathrm{L}$ in water bodies used for public water supply following conventional treatment [14]. For cyanotoxins, WHO suggests only the limit of $1.0 \mu \mathrm{g} / \mathrm{L}$ for microcystin-LR, which can be extrapolated to other microcystin variants [15]. In Brazil, limits established by legislation for cyanotoxins are $1.0 \mu \mathrm{g} / \mathrm{L}$ for microcystins and $3.0 \mu \mathrm{g} / \mathrm{L}$ for saxitoxins [16].

It is impossible to morphologically differentiate producing and non-producing strains [17]; hence, the presence of species known to produce cyanotoxins in blooms indicates the need for monitoring of the area to avoid harm to the environment and health of humans and animals. Due to the description of gene clusters responsible for biosynthesis of various types of cyanotoxins, it is possible to use molecular biology to evaluate the possible toxigenic capacity of cyanobacterial blooms using PCR technique. There are numerous examples of studies demonstrating a correlation between presence of genes and toxin production and the usefulness of molecular biology techniques [18-24]. Nevertheless, there is no consensus on which gene would be most appropriate to infer the presence of toxins $[18,20,21,25,26]$. Despite the full description of gene clusters responsible for the production of toxins, studies evaluating more than one gene are still not many when compared to studies evaluating one gene alone [11,27-35].

Billings Reservoir, the largest water resource of São Paulo Metropolitan Region (RMSP) in Brazil, has been monitored for the presence of cyanobacteria and cyanotoxins [36-41] by CETESB (Companhia Ambiental do Estado de São Paulo), an agency of the state government of São Paulo responsible for control, supervision, monitoring and licensing of pollution-generating activities. In the last available monitoring report [42], cyanobacteria were dominant in all points on the reservoir, with concomitant presence of microcystin. In addition to the monitoring conducted by CETESB using ELISA technique, the presence of cyanotoxins at Billings Reservoir was also shown by additional studies [20,37,42-44] using mass spectrometry to identify and quantify mainly microcystin; the presence of the $m c y B$ gene was additionally detected in one of the studies [20]. Saxitoxin is also monitored by CETESB; among the aforementioned studies, Anjos and colleagues [20] and Moschini-Carlos and colleagues [44] have both found variants of saxitoxin; the latter also evaluated the presence of cylindrospermopsin and anatoxin, with negative results. These results point out the recurrence of cyanobacterial blooms and the presence of cyanotoxins in Billings Reservoir.

The aim of this work was to evaluate the presence of multiple genes from each of the clusters responsible for cyanotoxin biosynthesis in natural samples of Billings Reservoir, as well as cyanobacteria composition and diversity.

The results of this work showed differential amplification for the cylindropermopsin and saxitoxin genes analyzed. Forty-one different cyanobacterial species were identified, and among these, several potentially cyanotoxin-producing species and genera were found, such as Microcystis aeruginosa, Planktothrix and Woronichinia. Based on our results, we suggest caution when using a single gene to infer the presence of toxins as it may not be sufficient to confirm or exclude the possibility of cyanotoxin production.

\section{Materials and Methods}

\subsection{Area of Study}

Billings Reservoir is located in the metropolitan region of São Paulo and is used for multiple purposes, from recreation to public water supply for the population of this region. Because of various blooms of cyanobacteria and deterioration of water quality, the reservoir was subdivided into five compartments (Central Body-I, Central Body-II, Taquacetuba-Bororé, Rio Grande-Rio Pequeno and Capivari-Pedra Branca) with the objective of improving management and monitoring of the area $[37,44,45]$. One of these compartments, named Central Body-I (CB-I), was chosen for evaluation 
in this study due to its various cyanobacterial blooms with recurrent presence of potentially toxic species, such as Microcystis aeruginosa and genera Plankthotrix and Woronichinia [46]. In CB-1, CETESB has monitored the composition of cyanobacteria since 2005 and the presence of cyanotoxins since 2007. In the last decade, microcystin was constantly detected while saxitoxin was reported only in 2004 and 2007 [20,44,46-53].

In this work, CB-I was subdivided into four sampling points (SP1-SP4) with the objective of covering most of the area. These points were selected based on the presence of different environmental contributions (Figure 1). SP1 is near the area where two heavily polluted rivers (Pinheiros and Tietê) have their flow direction usually reversed to the reservoir in order to prevent floods in RMSP; SP2 is close to remnant vegetation area; SP3 is closely located to a dense urban occupation area; and SP4 covered the beginning of Taquacetuba Arm, where water from Billings Reservoir is transferred to Guarapiranga Reservoir, another important reservoir in RMSP, which is also used for public supply.

a

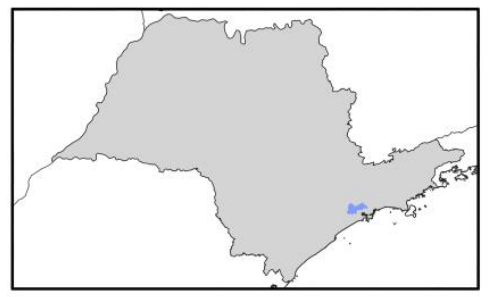

b

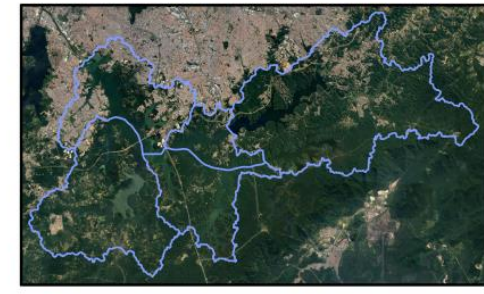

C

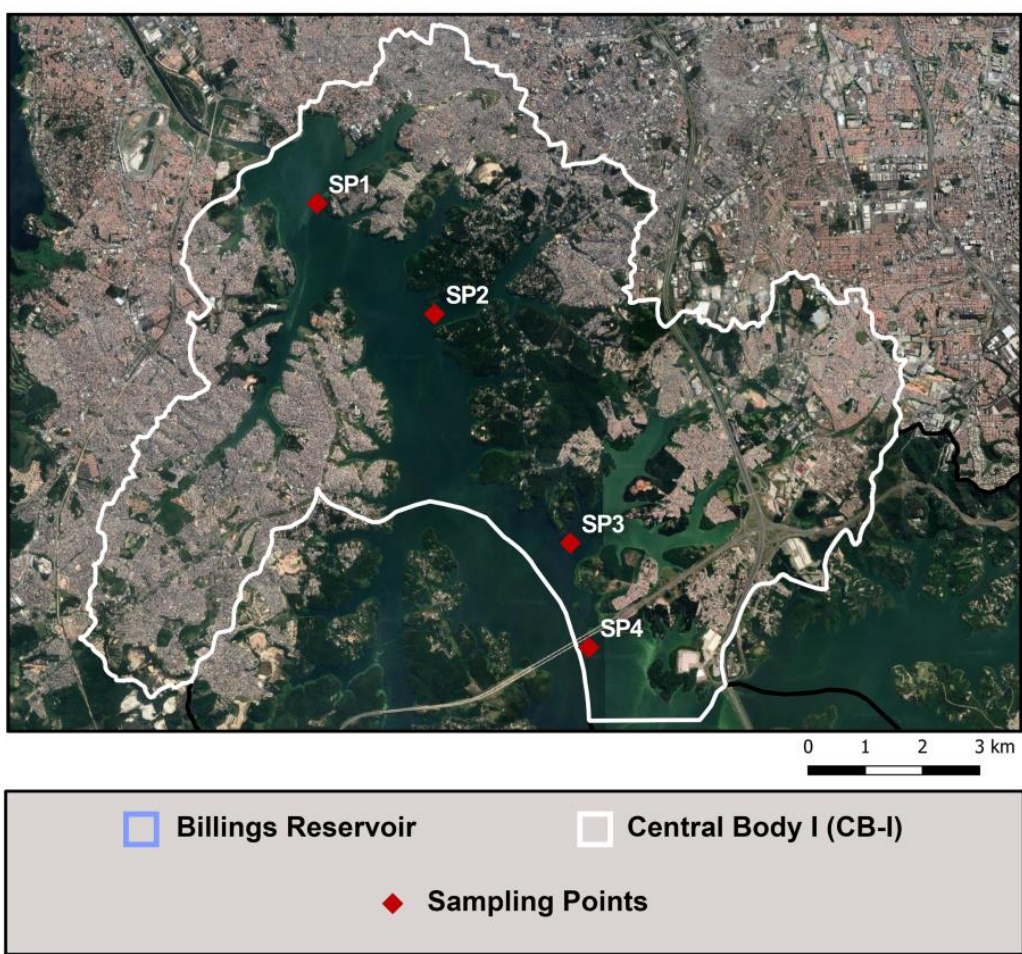

Figure 1. Location and sampling points of Billings Reservoir. (a) State of São Paulo, Billings Reservoir in blue. (b) Billings Reservoir subdivided into five compartments as per Brazilian regulation. (c) Central Body-I, sampling points in red.

\subsection{Sampling}

Sampling was carried out during rainy (Rainy 1-January 2017 and Rainy 2-February 2018) and dry (Dry 1-August 2016 - and Dry 2-August 2017) seasons. Water samples were collected using: (a) phytoplankton net (20-micrometer mesh) for qualitative analysis for phytoplankton identification $(100 \mathrm{~mL})$ and DNA extraction $(100 \mathrm{~mL})$ and $(\mathrm{b})$ Van Dorn bottle, for counts of cyanobacteria and 
eukaryotic microalgae $(100 \mathrm{~mL})$. Both sampling techniques were performed on the surface of a water column $(0.50 \mathrm{~m})$. All samples were stored and transported at $4{ }^{\circ} \mathrm{C}$ until processing after no more than 2 hours from sampling.

\subsection{DNA Extraction from the Microbial Community}

DNA extraction was performed using PowerWater ${ }^{\circledR}$ DNA Isolation Kit (MOBIO Laboratories, Inc., Carlsbad, CA, USA), except for the initial filtration step, that was replaced by centrifugation $(4.000 \times \mathrm{g}$ for $10 \mathrm{~min})$ of a sample of $30 \mathrm{~mL}$. Purity, quantity and quality of each extracted DNA were evaluated by absorbance measurement at A260/280 $\mathrm{nm}$ and visualization at $0.8 \%$ agarose gel. DNAs samples were stored at $-20^{\circ} \mathrm{C}$ until the moment of PCR reactions.

\subsection{Amplification of the Cyanotoxin Genes}

To verify the quality of DNA extracts for amplification, these were first analyzed with primers that amplify phycocyanin operon ( $c p c$ gene), including a variable intergenic spacer according to the previously described protocol [54]. All primers used in this work are listed in Table 1, along with sequence, annealing temperature (AT), fragment size and reference. All PCR reactions were performed in total volume of $25 \mu \mathrm{L}$, which contained: $1 \times$ PCR Buffer (Invitrogen), $2 \mathrm{mM} \mathrm{MgCl}_{2}$ (Invitrogen), $200 \mu \mathrm{M}$ of each DNTP (Invitrogen), $0.4 \mathrm{mM}$ of each primer, 1.5 U TAQ DNA Polymerase (Invitrogen) and $50 \mathrm{ng}$ of either total extracted DNA or genomic DNA of cultured samples used as positive control. For each PCR reaction, cycling conditions available in the references of each primer were used (Table 1). All PCR reactions were performed on a Veriti ${ }^{\text {TM }}$ 96-Well Thermal Cycler (Applied Biosystems, Foster City, CA, USA). Negative control consisted of all reagents required to perform a PCR reaction without any DNA sample.

Table 1. List of primers used in this study.

\begin{tabular}{|c|c|c|c|c|c|}
\hline $\begin{array}{l}\text { Target } \\
\text { Gene }\end{array}$ & Primer & Sequence $\left(5^{\prime}-3^{\prime}\right)$ & $\operatorname{AT}\left({ }^{\circ} \mathrm{C}\right)$ & $\begin{array}{l}\text { Fragment } \\
\text { Size (bp) }\end{array}$ & Reference \\
\hline$c p c$ & PC $\beta F$ & GGCTGCTTGTTTACGCGACA & 50 & $500-700$ & \multirow{2}{*}{ [54] } \\
\hline \multirow[b]{2}{*}{ cyrA } & $\begin{array}{l}\mathrm{PC} \alpha \mathrm{R} \\
\mathrm{CatF} 1\end{array}$ & $\begin{array}{l}\text { CCAGTACCACCAGCAACTAA } \\
\text { AGATGGTGCTTATTTTGAAC }\end{array}$ & \multirow[b]{2}{*}{54} & \multirow[b]{2}{*}{881} & \\
\hline & CatR1 & TCTTCACAGATGACCTTCTT & & & [27] \\
\hline \multirow{2}{*}{ cyrB } & CPS-F & AGTATATGTTGCGGGACTCG & \multirow{2}{*}{55} & \multirow{2}{*}{478} & \multirow{2}{*}{ [55] } \\
\hline & CPS-R & CCCGCCAAGACAGAGGGTAG & & & \\
\hline \multirow{2}{*}{ cyrC } & CkcF3 & AATGATCGAAAACAGCAGTCGG & \multirow[b]{2}{*}{54} & \multirow[b]{2}{*}{325} & \multirow{2}{*}{ [27] } \\
\hline & CkcR3 & TAGAACAATCATCCCACAACCT & & & \\
\hline \multirow{2}{*}{ cyrJ } & cyrJ-F & ТТСТСТССТТТСССТАТСТСТТТАТСТ & \multirow[b]{2}{*}{53} & \multirow[b]{2}{*}{536} & \multirow{2}{*}[26,56]{$^{*}$} \\
\hline & cyrJ-R & GCTACGGTGCTGTACCAAGGGGC & & & \\
\hline \multirow{2}{*}{$m c y E$} & mcyE-F2 & GAAATTTGTGTAGAAGGTGC & \multirow{2}{*}{56} & \multirow{2}{*}{$809-812$} & \multirow{2}{*}{ [57] } \\
\hline & mcyE-R4 & AATTCTAAAGCCCAAAGACG & & & \\
\hline \multirow{2}{*}{$s x t A$} & sxtA-F & GATGACGGAGTATTTGAAGC & \multirow{2}{*}{55} & \multirow{2}{*}{125} & \multirow{2}{*}{ [18] } \\
\hline & sxtA-R & CTGCATCTTCTGGACGGTAA & & & \\
\hline \multirow{2}{*}{$s x t B$} & SXTB-F & TTTGTAGGRCAGGCACTT & \multirow{2}{*}{53} & \multirow{2}{*}{400} & \multirow{2}{*}{ [26] } \\
\hline & SXTB-R & ATCATCGGTATCATCGGTA & & & \\
\hline \multirow{2}{*}{ sxtI } & OCT-F & TGCCGTTTTGTGCTTAGATG & \multirow{2}{*}{61} & \multirow{2}{*}{923} & \multirow{2}{*}{ [26] } \\
\hline & OCT-R & GGACGGAAGGACTCACGATA & & & \\
\hline
\end{tabular}

\subsection{Cyanobacteria Strains}

Microcystis aeruginosa (NPLJ-04), Raphidiopsis raciborskii (T3) and Raphidiopsis raciborskii (CYP-011K) strains previously confirmed as microcystin, saxitoxin and cylindrospermopsin producers, respectively [26,58], were used as positive controls for PCR reactions. These strains were grown on MLA medium [59], at 12:12 h light/dark cycle and $25 \pm 1{ }^{\circ} \mathrm{C}$. DNA extraction from cultured strains was performed using the same kit and extraction method as that for microbial community. The strains 
NPLJ-04, T3 and CYP-011K were kindly provided by Sandra Azevedo, Ph.D, Federal University of Rio de Janeiro.

\subsection{Cyanobacteria and Eukaryotic Microalgae Identification and Density}

Cyanobacteria and eukaryotic microalgae were identified by their morphometric characteristics. Phytoplankton counts were performed using sedimentation chambers ( $5 \mathrm{~mL}$ ) on a Carl Zeiss Inverted Microscope, 400× augmentation, and limit criteria were as established previously by other authors [60,61]. After counting, densities were converted to biovolume $\left(\mathrm{mm}^{3} / \mathrm{L}\right)$ using each taxon-specific biovolume from previous publications [62,63]. All samples used for counts were preserved in Lugol solution (1\%), in the dark and at room temperature. Samples used for identification were preserved in formalin (4\%) and stored under the same conditions described above.

\section{Results}

\subsection{Amplification of Cyanotoxin Genes}

Eight genes involved in the biosynthesis of microcystin, cylindrospermopsin and saxitoxin were evaluated by PCR from total DNA of the microbial community (Table 2 and Figure S1). The amplification reaction of phycocyanin operon was positive for all analyzed samples, confirming the presence of cyanobacterial genetic material.

Table 2. PCR results.

\begin{tabular}{|c|c|c|c|c|c|c|c|c|c|c|c|c|c|c|c|c|}
\hline \multirow{2}{*}{ Gene } & \multicolumn{4}{|c|}{ DRY 1} & \multicolumn{4}{|c|}{ DRY 2} & \multicolumn{4}{|c|}{ RAINY 1} & \multicolumn{4}{|c|}{ RAINY 2} \\
\hline & SP1 & SP2 & SP3 & SP4 & SP1 & SP2 & SP3 & SP4 & SP1 & SP2 & SP3 & SP4 & SP1 & SP2 & SP3 & SP4 \\
\hline$c p c$ & + & + & + & + & + & + & + & + & + & + & + & + & + & + & + & + \\
\hline$m c y E$ & + & + & + & + & + & + & + & + & + & + & + & + & + & + & + & + \\
\hline cyrA & - & - & - & - & - & - & - & - & - & - & - & - & - & - & - & - \\
\hline cyrB & + & - & - & - & - & - & - & - & - & - & - & - & - & - & - & - \\
\hline cyrC & + & + & + & + & - & - & - & - & - & - & - & - & + & + & - & - \\
\hline cyrJ & - & - & - & - & - & - & - & - & - & - & - & - & - & - & - & - \\
\hline$s x t A$ & - & - & - & - & - & - & - & - & - & - & - & - & - & - & - & - \\
\hline$s x t B$ & + & - & + & + & - & - & - & - & - & - & - & - & - & - & - & - \\
\hline$s x t I$ & - & - & - & - & - & - & + & - & - & - & - & - & - & - & + & + \\
\hline
\end{tabular}

DRY = sampling during dry periods, RAINY = sampling during rainy periods. +: positive results, - : negative results.

The microcystin gene $m c y E$ was amplified in all investigated samples. Four sets of primers were used to evaluate the presence of cylindrospermopsin genes and results showed that only the cyrC gene was amplified from DNA of all samples collected in Dry 1 and two samples (SP1 and SP2) in Rainy 2. In this work, $s x t A, s x t B$ and $s x t I$ genes were analyzed and no amplification was observed for the $s x t A$ gene. The $s x t B$ gene was present in all samples in Dry 1 except for SP2, while the sxtI gene was amplified in only one sample in Dry 2 (SP3) and two samples in Rainy 2 (SP3 and SP4). Monitoring by CETESB provides data on microcystin concentrations collected at sampling times that correspond to those in this work. For samplings performed during dry season, microcystin concentrations were under lower limit of detection for Dry $1(<0.15 \mu \mathrm{g} / \mathrm{L})$ and $1.36 \mu \mathrm{g} / \mathrm{L}$ for Dry 2. For samplings carried out during rainy season, concentrations were $14.5 \mu \mathrm{g} / \mathrm{L}$ for Rainy 1 and $50.0 \mu \mathrm{g} / \mathrm{L}$ for Rainy 2 [42,46,53]. Saxitoxin was not detected in samples analyzed during this period by CETESB, and cylindrospermopsin is not part of CETESB monitoring [46,53].

\subsection{Cyanobacteria Composition}

Forty-one cyanobacteria species were identified, and all taxa are described in Table S1. Species Synechocystis aquatilis, Aphanocapsa annulata, Microcystis aeruginosa, Planktolyngbya limnetica, Pseudanabaena mucicola, Synechococcus nidulans and Woronichinia naegeliana were present in most of the samples obtained in the period under study. Species Aphanotece zulanirae, Chroococcus dispersus, 
Cyanodictyon planctonicum, Dolichospermum mucosum, Dolichospermum sp., Dolichospermum spiroides, Microcystis botrys, Microcystis panniformis, Planktothrix isothrix and Synechococcus elongatus were found exclusively during the dry season, while species Aphanizomenon gracile, Aphanocapsa elachista, Aphanocapsa incerta, Chroococcus dispersus, Coelomorum pusillum, Eucapsis densa, Geitlerinema splendidum, Merismopedia tenuissima, Pseudanabaena galeata and Rhabdoderma sancti-pauli were found exclusively during the rainy period. During the entire sampling period, eleven species were dominant or abundant in relation to other components of phytoplankton using biovolume as comparison unit (Figure 2), namely, Aphanocapsa annulata, Coelosphaerium evidenter-marginatum, Dolichospermum mucosum, Dolichospermum nygaardii, Dolichospermum sp., Merismopedia tenuissima, Microcystis aeruginosa, Microcystis panniformis, Microcystis protocystis, Synechocystis aquatilis, and Woronichinia naegeliana.

\subsection{Cyanobacteria Biovolume}

Comparing sampling periods, cyanobacterial biovolume was higher in the dry season than in the rainy one (Figure 3). Furthermore, very high biovolume values were observed in this study. Such high values can be explained mainly by dominance of the species Woronichinia naegeliana at all points during drought and the presence of abundant species Woronichinia naegeliana and Microcystis aeruginosa during rainy periods (Figure 2).

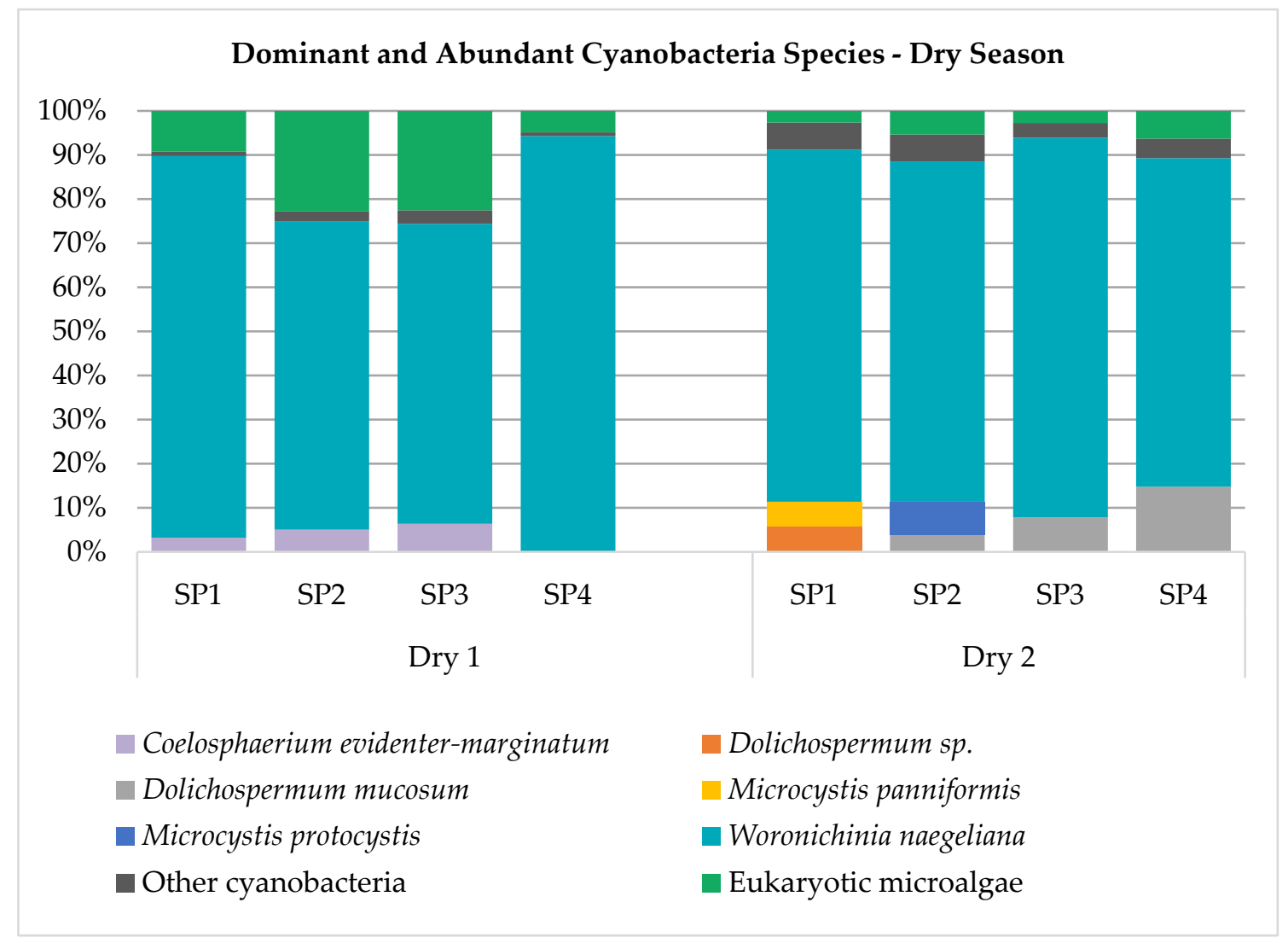

Figure 2. Cont. 


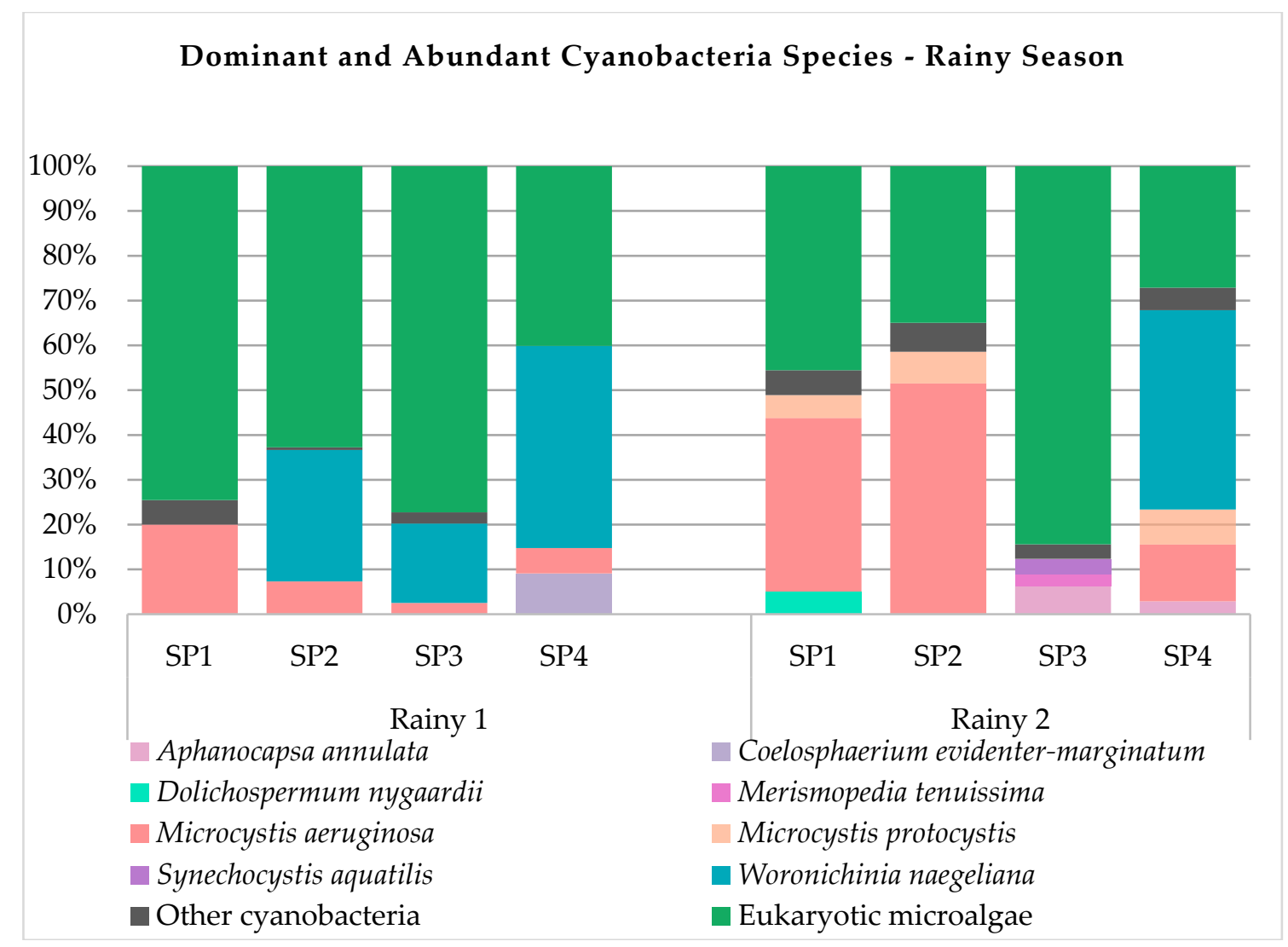

Figure 2. Dominant and abundant cyanobacteria species.

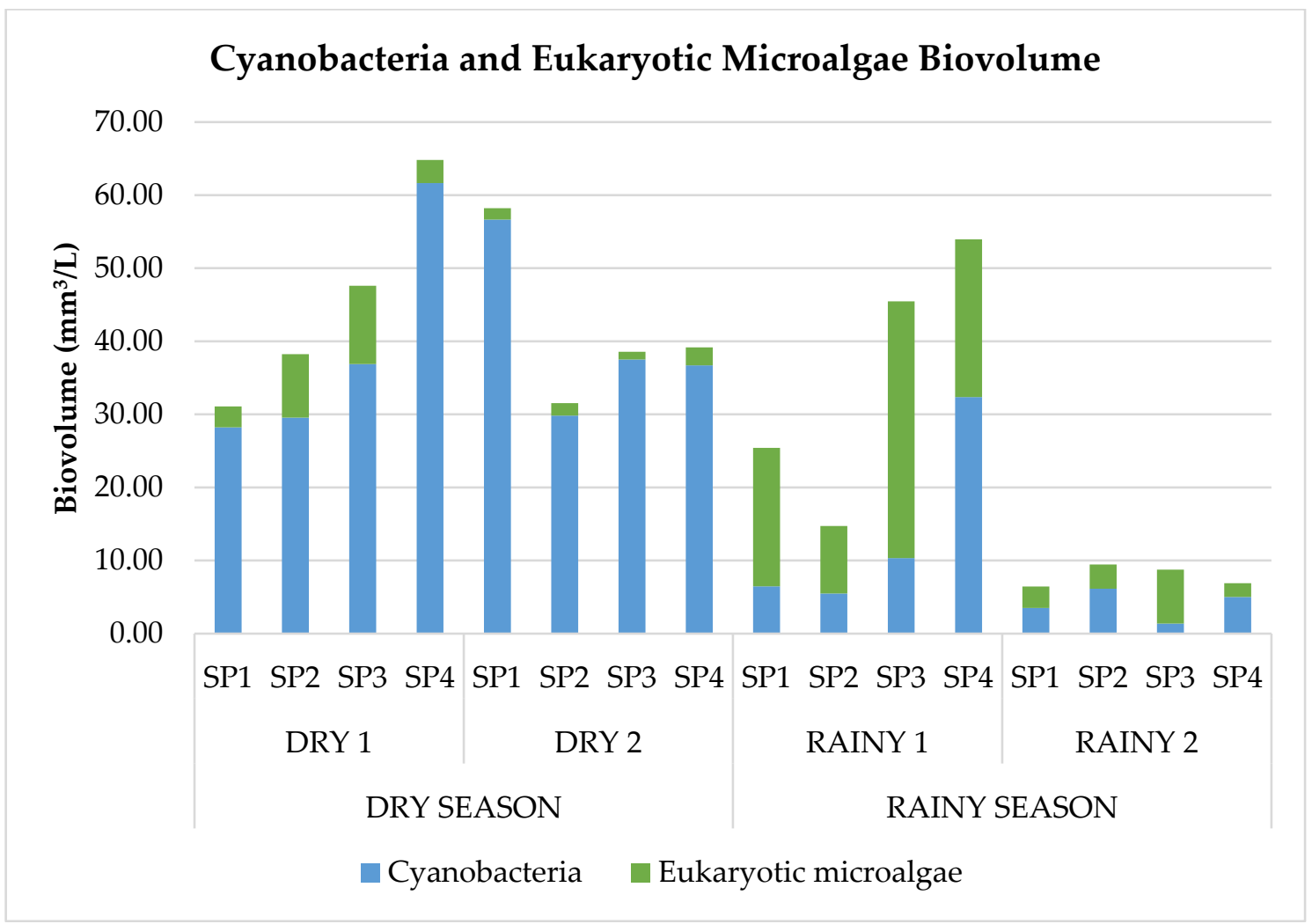

Figure 3. Cyanobacteria vs. eukaryotic microalgae biovolume. 


\section{Discussion}

In cases of bloom events caused by cyanobacteria in reservoirs that are used for water supply, rapid discrimination between toxic (CyanoHABs) and non-toxic blooms is of great importance as basis for surveillance and management actions according to WHO recommendations [64]. Description of genetic clusters responsible for cyanotoxin biosynthesis made it possible to analyze the presence of genes and indirectly infer the presence of toxins in samples [27,57]. Hence, the use of molecular biology techniques presents itself as a very useful tool, considering that results can be obtained quickly.

There are several studies suggesting biosynthesis pathways for microcystin, saxitoxin and cylindrospermopsin, based on strains such as Microcystis aeruginosa PCC7806, Aphanizomenon sp. NH-5, Raphidiopsis raciborskii AWT205, Oscillatoria sp. PCC 6506 and Anabaena circinalis AWQC131C [55,56,65-67]. In this work, genes chosen for analysis were described in crucial steps of cyanotoxin biosynthesis and environmental samples studied were selected according to the monitoring data obtained by CETESB $[46,52,53]$. Importantly, the DNA extraction methodology applied in this study allowed the extraction of high-quality DNA that is susceptible to amplification, without inhibitors or substances that might interfere in the PCR reaction.

The detection of the $m c y E$ gene in all samples could be related to the presence of microcystin in 3 of 4 samplings $[42,46,53]$. These data support the feasibility of using molecular biology techniques for rapid and indirect cyanotoxin monitoring in aquatic environments. The $m c y E$ gene is involved in the formation and modification of the side chain of the Adda amino acid, present in all microcystin molecules, including variants. The biosynthesis pathway of this toxin has 6 more steps until completion of the molecule $[67,68]$. It is considered the best target as it can be amplified even in samples with low cyanobacterial biomass concentration and is also involved in crucial biosynthesis steps, supporting our findings $[69,70]$. Gene expression evaluation in environmental samples is the next step in further understanding whether there is a relationship between cyanotoxin concentrations in water and gene expression, considering that the detection of cyanotoxin-producing genes in total DNA samples obtained from environmental samples is still carried out through PCR technique.

Saxitoxin and cylindrospermopsin genes were detected in only some samples, but their relation to the presence of toxins in water could not be confirmed. Sets of three and four primers were analyzed for detection of genes essential for biosynthesis of saxitoxin and cylindrospermopsin, respectively, and differential amplification between genes was observed for both toxins. Genes cyr $A, \operatorname{cyr} B$ and $c y r C$ act sequentially on cylindrospermopsin biosynthesis. The cyrA gene is the first to be activated and is involved in the formation of guanidinoacetate, a precursor that is activated by the next enzyme in the pathway, encoded by the $c y r B$ gene. The $c y r C$ gene encodes a nonribosomal peptide synthetase-polyketide synthase (NRPS-PKS) enzyme responsible for elongation of the cylindrospermopsin carbonic chain. The biosynthesis pathway of cylindrospermopsin requires tailoring reactions, i.e., reactions performed by enzymes that make additional modifications to the molecule before it is complete. The cyrJ gene is involved in these steps, in a sulfation reaction $[65,68]$. The $s x t A$ gene, the first of the saxitoxin biosynthesis pathway, encodes an enzyme responsible for forming the saxitoxin precursor, 4-amino-3-oxo-guanidinoheptane, which is later converted to 4,7-diguanidino-3-oxoheptane by another enzyme (encoded by $s x t G$ ). The $s x t B$ gene is involved in the onset of cyclization of the latter molecule, while the sxtI gene is involved in a transfer reaction of a carbamoyl group to the saxitoxin molecule, one of the last biosynthesis reactions in this pathway [68,71].

To date, few studies have evaluated the presence of several genes of clusters responsible for biosynthesis of microcystin, cylindrospermopsin and saxitoxin in environmental samples [11,27-35], when compared to the majority of studies in which only one gene is used. Of these, five [28,30,33-35] reported results similar to those obtained in this work, i.e., differential amplification between genes responsible for biosynthesis of a cyanotoxin. When one or more of these genes considered as crucial to the biosynthesis of cyanotoxins mutates or is deleted, synthesis of the cyanotoxin in question would be disrupted or impaired even when other genes in the cluster are present. 
Accordingly, we suggest caution when using only one gene from the full cluster as it may not be sufficient to confirm the cyanotoxin production capacity in a sample. For example, a positive PCR result for the detection of a single gene within a full cluster does not necessarily entail cyanotoxin production given that other genes are needed for that (false-positive result). Moreover, if there is a silent point mutation at the primer annealing site that does not change the reading frame for transcription and translation, the mutated gene may not be detected, leading to a false-negative result. At last, there may be other biosynthetic pathways not yet known or described.

The composition of species present in Billings Reservoir was also monitored during the studied period, as a way of identifying or correlating species and genes. Some species of cyanobacteria, such as Microcystis aeruginosa and Raphidiopsis raciborskii $[12,26]$, are constantly reported as potential cyanotoxin producers; the first one was found in samples of this study. There were no distinctive differences between composition and biovolume of cyanobacteria observed at sampling points, indicating that distribution of cyanobacteria is homogenous in CB-I of Billings Reservoir.

The species Woronichinia naegeliana was dominant during most of the studied period and is reported in the literature as a potential microcystin and anatoxin-a producer [72-74]. Moreover, other species and genera that were abundant and even rare during the studied period can be related to the presence of the mcyE gene, such as Microcystis aeruginosa, Synechocystis aquatilis, Dolichospermum spp and Aphanocapsa spp [12,75].

In the literature, some species are constantly indicated as potential cylindrospermopsin producers, such as Aphanizomenon aphanizomenoides, Aphanizomenon flos-aquae, Aphanizomenon ovalisporum, Raphidiopsis raciborskii, Dolichospermum lapponica, Umezakia natans and Lyngbya wollei $[7,26]$. These species were not found in our work, but cylindrospermopsin genes were detected ( $c y r B$ and $c y r C$ ). This fact may suggest there are species not yet described as cylindrospermopsin producers that are responsible for biosynthesis of this cyanotoxin in Brazilian reservoirs, a hypothesis already raised before by other authors [26]. As cultivation and isolation of cyanobacteria were not performed in this study, it was not possible to verify or evaluate the relation between certain genes and species; this may serve as basis for future works.

\section{Conclusions}

Based on the results presented on this work, we suggest caution when using only one gene from the full cluster as it may not be sufficient to confirm the cyanotoxin production capacity. The detection of the gene in the microcystin biosynthesis cluster obtained in all samples supported the results obtained by CETESB in the same portion of Billings Reservoir indicating the presence of microcystin. Concomitant detection of cyanotoxin-producing genes and potentially cyanotoxin-producing species highlights the potential of PCR technique as a monitoring tool.

Supplementary Materials: The following are available online at http://www.mdpi.com/2073-4441/12/3/903/s1, Figure S1. PCR results; Table S1. List of species found in the study.

Author Contributions: Conceptualization, C.V.-N., C.S.F.N., M.S.F.R.; methodology, M.S.F.R., M.P.M.; validation, M.S.F.R.; formal analysis, C.V.-N., C.S.F.N., M.S.F.R., A.T.; writing-original draft preparation, C.V.-N., C.S.F.N., M.S.F.R.; writing-review and editing, C.V.-N., C.S.F.N., M.S.F.R.; supervision, C.V.-N.; project administration, C.V.-N., C.S.F.N.; funding acquisition, C.V.-N, C.S.F.N. All authors have read and agreed to the published version of the manuscript.

Funding: This research was funded by São Paulo Research Foundation (FAPESP), grant numbers 2010/52641-1 and 2010/50738-8, and M.S.F.R was funded by Coordenação de Aperfeiçoamento de Pessoal de Nível Superior-Brasil (CAPES), grant number (finance number) 001.

Conflicts of Interest: The authors declare no conflict of interest. 


\section{References}

1. Saad, A.; Atia, A. Review on freshwater blue-green algae (cyanobacteria): Occurrence, classification and toxicology. Biosci. Biotechnol. Res. Asia 2014, 11, 1319-1325. [CrossRef]

2. Rastogi, R.P.; Madamwar, D.; Incharoensakdi, A. Bloom Dynamics of Cyanobacteria and Their Toxins: Environmental Health Impacts and Mitigation Strategies. Front. Microbiol. 2015, 6, 1254. [CrossRef] [PubMed]

3. Backer, L.C. Cyanobacterial Harmful Algal Blooms (CyanoHABs): Developing a Public Health Response. Lake Reserv. Manag. 2002, 18, 20-31. [CrossRef]

4. Carmichael, W.W.; Azevedo, S.M.; An, J.S.; Molica, R.J.; Jochimsen, E.M.; Lau, S.; Rinehart, K.L.; Shaw, G.R.; Eaglesham, G.K. Human fatalities from cyanobacteria: Chemical and biological evidence for cyanotoxins. Environ. Health Perspect. 2001, 109, 663-668. [CrossRef]

5. Chun, S.-J.; Cui, Y.; Lee, C.S.; Cho, A.R.; Baek, K.; Choi, A.; Ko, S.-R.; Lee, H.-G.; Hwang, S.; Oh, H.-M.; et al. Characterization of Distinct CyanoHABs-Related Modules in Microbial Recurrent Association Network. Front. Microbiol. 2019, 10, 1637. [CrossRef]

6. Drobac, D.; Tokodi, N.; Simeunović, J.; Baltić, V.; Stanić, D.; Svirčev, Z. Human Exposure to Cyanotoxins and their Effects on Health. Arch. Ind. Hyg. Toxicol. 2013, 64, 305-316. [CrossRef]

7. Buratti, F.M.; Manganelli, M.; Vichi, S.; Stefanelli, M.; Scardala, S.; Testai, E.; Funari, E. Cyanotoxins: Producing organisms, occurrence, toxicity, mechanism of action and human health toxicological risk evaluation. Arch. Toxicol. 2017, 91, 1049-1130. [CrossRef]

8. He, X.; Liu, Y.L.; Conklin, A.; Westrick, J.; Weavers, L.K.; Dionysiou, D.D.; Lenhart, J.J.; Mouser, P.J.; Szlag, D.; Walker, H.W. Toxic cyanobacteria and drinking water: Impacts, detection, and treatment. Harmful Algae 2016, 54, 174-193. [CrossRef]

9. Aguilera, A.; Gómez, E.B.; Kaštovský, J.; Echenique, R.O.; Salerno, G.L. The polyphasic analysis of two native Raphidiopsis isolates supports the unification of the genera Raphidiopsis and Cylindrospermopsis (Nostocales, Cyanobacteria). Phycologia 2018, 57, 130-146. [CrossRef]

10. Bittencourt-Oliveira, M.D.C.; Piccin-Santos, V.; Moura, A.N.; Aragão-Tavares, N.K.C.; Cordeiro-Araújo, M.K. Cyanobacteria, microcystins and cylindrospermopsin in public drinking supply reservoirs of Brazil. Anais da Academia Brasileira de Ciências 2014, 86, 297-309. [CrossRef]

11. Park, H.-K.; Kwon, M.-A.; Lee, H.-J.; Oh, J.; Lee, S.-H.; Kim, I.-S.; Park, H.-K.; Kwon, M.-A.; Lee, H.-J.; Oh, J.; et al. Molecular Verification of Bloom-forming Aphanizomenon flos-aquae and Their Secondary Metabolites in the Nakdong River. Int. J. Environ. Res. Public Health 2018, 15, 1739. [CrossRef] [PubMed]

12. Svirčev, Z.; Drobac, D.; Tokodi, N.; Mijović, B.; Codd, G.A.; Meriluoto, J. Toxicology of microcystins with reference to cases of human intoxications and epidemiological investigations of exposures to cyanobacteria and cyanotoxins. Arch. Toxicol. 2017, 91, 621-650. [CrossRef] [PubMed]

13. World Health Organization. Toxic Cyanobacteria in Water: A Guide to Their Public Health Consequences, Monitoring, and Management; Chorus, I., Bartram, J., Eds.; CRC Press: Boca Raton, FL, USA, 1999; ISBN 0419239308.

14. Conselho Nacional do Meio Ambiente. Resolução $n^{\circ}$ 357, de 17 de março de 2005; Resolução $n^{\circ} 357$, DOU $n^{\circ}$ 053; Conselho Nacional Do Meio Ambiente: Brasília, Brazil, 2005.

15. World Health Organization. Guidelines for Drinking-Water Quality, 4th ed.; World Health Organization, Ed.; World Health Organization: Geneva, Switzerland, 2017; ISBN 9789241549950.

16. Ministério da Saúde. Portaria de Consolidação nº 5, de 28 de Setembro de 2017; Ministério da Saúde: Bebedouro, Brazil, 2017.

17. Janse, I.; Kardinaal, W.E.A.; Meima, M.; Fastner, J.; Visser, P.M.; Zwart, G. Toxic and nontoxic microcystis colonies in natural populations can be differentiated on the basis of rRNA gene internal transcribed spacer diversity. Appl. Environ. Microbiol. 2004, 70, 3979-3987. [CrossRef] [PubMed]

18. Al-Tebrineh, J.; Mihali, T.K.; Pomati, F.; Neilan, B.A. Detection of saxitoxin-producing cyanobacteria and Anabaena circinalis in environmental water blooms by quantitative PCR. Appl. Environ. Microbiol. 2010, 76, 7836-7842. [CrossRef]

19. Al-Tebrineh, J.; Merrick, C.; Ryan, D.; Humpage, A.; Bowling, L.; Neilan, B.A. Community composition, toxigenicity, and environmental conditions during a cyanobacterial bloom occurring along 1100 kilometers of the Murray River. Appl. Environ. Microbiol. 2012, 78, 263-272. [CrossRef] 
20. dos Anjos, F.M.; do Bittencourt-Oliveira, M.C.; Zajac, M.P.; Hiller, S.; Christian, B.; Erler, K.; Luckas, B.; Pinto, E. Detection of harmful cyanobacteria and their toxins by both PCR amplification and LC-MS during a bloom event. Toxicon 2006, 48, 239-245. [CrossRef]

21. Baker, J.A.; Entsch, B.; Neilan, B.A.; McKay, D.B. Monitoring changing toxigenicity of a cyanobacterial bloom by molecular methods. Appl. Environ. Microbiol. 2002, 68, 6070-6076. [CrossRef]

22. Belykh, O.I.; Gladkikh, A.S.; Sorokovikova, E.G.; Tikhonova, I.V.; Potapov, S.A.; Butina, T.V. SaxitoxinProducing cyanobacteria in Lake Baikal. Contemp. Probl. Ecol. 2015, 8, 186-192. [CrossRef]

23. Sidelev, S.I.; Golokolenova, T.B.; Chernova, E.N.; Russkikh, Y.V. Analysis of phytoplankton in Tsimlyansk Reservoir (Russia) for the presence of cyanobacterial hepato- and neurotoxins. Microbiology 2015, 84, 828-837. [CrossRef]

24. Kurmayer, R.; Sivonen, K.; Wilmotte, A.; Salmaso, N. Molecular Tools for the Detection and Quantification of Toxigenic Cyanobacteria, 1st ed.; Wiley: Hoboken, NJ, USA, 2017; pp. 163-203.

25. do Bittencourt-Oliveira, M.C.; Piccin-Santos, V.; Kujbida, P.; do Moura, A.N. Cylindrospermopsin in Water Supply Reservoirs in Brazil Determined by Immunochemical and Molecular Methods. J. Water Resour. Prot. 2011, 03, 349-355. [CrossRef]

26. Hoff-Risseti, C.; Dörr, F.A.; Schaker, P.D.C.; Pinto, E.; Werner, V.R.; Fiore, M.F. Cylindrospermopsin and Saxitoxin Synthetase Genes in Cylindrospermopsis raciborskii Strains from Brazilian Freshwater. PLoS ONE 2013, 8, e74238. [CrossRef] [PubMed]

27. Barón-Sola, Á.; Ouahid, Y.; del Campo, F.F. Detection of potentially producing cylindrospermopsin and microcystin strains in mixed populations of cyanobacteria by simultaneous amplification of cylindrospermopsin and microcystin gene regions. Ecotoxicol. Environ. Saf. 2012, 75, 102-108. [CrossRef] [PubMed]

28. Li, L.; Jia, R.; Liu, Y.; Zhang, H. Detection of Microcystin-Producing Cyanobacteria in a Reservoir by Whole Cell Quantitative PCR. Procedia Environ. Sci. 2011, 10, 2272-2279. [CrossRef]

29. Macário, I.P.E.; Castro, B.B.; Nunes, I.M.S.; Pizarro, C.; Coelho, C.; Gonçalves, F.; de Figueiredo, D.R. Stepwise strategy for monitoring toxic cyanobacterial blooms in lentic water bodies. Environ. Monit. Assess. 2017, 189, 620. [CrossRef] [PubMed]

30. Legrand, B.; Lesobre, J.; Colombet, J.; Latour, D.; Sabart, M. Molecular tools to detect anatoxin-a genes in aquatic ecosystems: Toward a new nested PCR-based method. Harmful Algae 2016, 58, 16-22. [CrossRef] [PubMed]

31. Lorenzi, A.S.; Chia, M.A.; Piccin-Santos, V.; Do, M.; Bittencourt-Oliveira, C. Microcystins and cylindrospermopsins molecular markers for the detection of toxic cyanobacteria: A case study of northeastern Brazilian reservoirs. Limnetica 2011, 29, 269-282.

32. Zhang, W.; Lou, I.; Ung, W.K.; Kong, Y.; Mok, K.M. Analysis of cylindrospermopsin- and microcystinproducing genotypes and cyanotoxin concentrations in the Macau storage reservoir. Hydrobiologia 2014, 741, 51-68. [CrossRef]

33. Gkelis, S.; Papadimitriou, T.; Zaoutsos, N.; Leonardos, I. Anthropogenic and climate-induced change favors toxic cyanobacteria blooms: Evidence from monitoring a highly eutrophic, urban Mediterranean lake. Harmful Algae 2014, 39, 322-333. [CrossRef]

34. Gkelis, S.; Zaoutsos, N. Cyanotoxin occurrence and potentially toxin producing cyanobacteria in freshwaters of Greece: A multi-disciplinary approach. Toxicon 2014, 78, 1-9. [CrossRef]

35. Magana Arachchi, D.N.; Liyanage, H.M. Determining the presence of cyanotoxins in water reservoirs of anuradhapura, using molecular and bioassay methods. J. Natl. Sci. Found. Sri Lanka 2012, 40, 156-166. [CrossRef]

36. De Souza, R.C.R.; Carvalho, M.C.; Truzzi, A.C. Cylindrospermopsis raciborskii (Wolosz.) Seenaya and Subba Raju (Cyanophyceae) dominance and a contribution to the knowledge of Rio Pequeno Arm, Billings Reservoir, Brazil. Environ. Toxicol. Water Qual. 1998, 13, 73-81. [CrossRef]

37. de Carvalho, L.R.; Sant'Anna, C.L.; Gemelgo, M.C.P.; de P. Azevedo, M.T. Cyanobacterial occurrence and detection of microcystin by planar chromatography in surface water of Billings and Guarapiranga Reservoirs, SP, Brazil. Rev. Bras. Botânica 2007, 30, 141-148. [CrossRef]

38. Gemelgo, M.; Mucci, J.; Navas-Pereira, D. Population dynamics: Seasonal variation of phytoplankton functional groups in brazilian reservoirs (Billings and Guarapiranga, São Paulo). Braz. J. Biol. 2009, 69, 1001-1013. [CrossRef] [PubMed] 
39. Gemelgo, M.C.P.; Sant'Anna, C.L.; Tucci, A.; Barbosa, H.R. Population dynamics of Cylindrospermopsis raciborskii (Woloszynska) Seenayya \& Subba Raju, a Cyanobacteria toxic species, in watersupply reservoirs in São Paulo, Brazil. Hoehnea 2008, 35, 297-307.

40. Piccin-Santos, V.; do Bittencourt-Oliveira, M.C. Toxic Cyanobacteria in Four Brazilian Water Supply Reservoirs. J. Environ. Prot. 2012, 3, 68-73. [CrossRef]

41. Sant'Anna, C.L.; Melcher, S.S.; Carvalho, M.D.; Gelmego, M.P.; Azevedo, M.T. Planktic cyanobacteria from upper Tietê basin reservoirs, SP, Brazil. Rev. Bras. Bot. 2007, 30, 1-17. [CrossRef]

42. Companhia Ambiental do Estado de São Paulo. Qualidade das Águas Interiores no Estado de São Paulo 2018; São Paulo State Inland Water Quality Report; CETESB: São Paulo, Brazil, 2019.

43. Frias, H.V.; Mendes, M.A.; Cardozo, K.H.M.; Carvalho, V.M.; Tomazela, D.; Colepicolo, P.; Pinto, E. Use of electrospray tandem mass spectrometry for identification of microcystins during a cyanobacterial bloom event. Biochem. Biophys. Res. Commun. 2006, 344, 741-746. [CrossRef]

44. Moschini-Carlos, V.; Bortoli, S.; Pinto, E.; Nishimura, P.Y.; De Freitas, L.G.; Pompêo, M.L.M.; Dörr, F. Cyanobacteria and cyanotoxin in the billings reservoir (São Paulo, SP, Brazil). Limnetica 2009, 28, $273-282$.

45. Assembléia Legislativa do Estado de São Paulo. Lei No 13.579, de 13 de Julho de 2009; Assembléia Legislativa do Estado de São Paulo: São Paulo, Brazil, 2009; pp. 1-30.

46. Companhia Ambiental do Estado de São Paulo. Qualidade das Águas Interiores no Estado de São Paulo 2016; São Paulo State Inland Water Quality Report; CETESB: São Paulo, Brazil, 2017.

47. Companhia Ambiental do Estado de São Paulo. Qualidade das Águas Interiores no Estado de São Paulo 2010; São Paulo State Inland Water Quality Report; CETESB: São Paulo, Brazil, 2011.

48. Companhia Ambiental do Estado de São Paulo. Qualidade das Águas Interiores no Estado de São Paulo 2011; São Paulo State Inland Water Quality Report; CETESB: São Paulo, Brazil, 2012.

49. Companhia Ambiental do Estado de São Paulo. Qualidade das Águas Interiores no Estado de São Paulo 2012; São Paulo State Inland Water Quality Report; CETESB: São Paulo, Brazil, 2013.

50. Companhia Ambiental do Estado de São Paulo. Qualidade das Águas Interiores no Estado de São Paulo 2013; São Paulo State Inland Water Quality Report; CETESB: São Paulo, Brazil, 2014.

51. Companhia Ambiental do Estado de São Paulo. Qualidade das Águas Interiores no Estado de São Paulo 2014; São Paulo State Inland Water Quality Report; CETESB: São Paulo, Brazil, 2015.

52. Companhia Ambiental do Estado de São Paulo. Qualidade das Águas Interiores no Estado de São Paulo 2015; São Paulo State Inland Water Quality Report; CETESB: São Paulo, Brazil, 2016.

53. Companhia Ambiental do Estado de São Paulo. Qualidade das Águas Interiores no Estado de São Paulo 2017; São Paulo State Inland Water Quality Report; CETESB: São Paulo, Brazil, 2018.

54. Neilan, B.A.; Jacobs, D.; Goodman, A.E. Genetic diversity and phylogeny of toxic cyanobacteria determined by DNA polymorphisms within the phycocyanin locus. Appl. Environ. Microbiol. 1995, 61, 3875-3883. [CrossRef]

55. Kellmann, R.; Mills, T.; Neilan, B.A. Functional modeling and phylogenetic distribution of putative cylindrospermopsin biosynthesis enzymes. J. Mol. Evol. 2006, 62, 267-280. [CrossRef]

56. Mazmouz, R.; Chapuis-Hugon, F.; Mann, S.; Pichon, V.; Méjean, A.; Ploux, O. Biosynthesis of cylindrospermopsin and 7-epicylindrospermopsin in oscillatoria sp. strain PCC 6506: Identification of the cyr gene cluster and toxin analysis. Appl. Environ. Microbiol. 2010, 76, 4943-4949. [CrossRef]

57. Rantala, A.; Fewer, D.P.; Hisbergues, M.; Rouhiainen, L.; Vaitomaa, J.; Borner, T.; Sivonen, K. Phylogenetic evidence for the early evolution of microcystin synthesis. Proc. Natl. Acad. Sci. USA 2004, 101, 568-573. [CrossRef] [PubMed]

58. Laughinghouse, H.D.; Prá, D.; Silva-Stenico, M.E.; Rieger, A.; Frescura, V.D.S.; Fiore, M.F.; Tedesco, S.B. Biomonitoring genotoxicity and cytotoxicity of Microcystis aeruginosa (Chroococcales, Cyanobacteria) using the Allium cepa test. Sci. Total Environ. 2012, 432, 180-188. [CrossRef] [PubMed]

59. Bolch, C.J.S.; Blackburn, S.I. Isolation and purification of Australian isolates of the toxic cyanobacterium Microcystis aeruginosa Kütz. J. Appl. Phycol. 1996, 8, 5-13. [CrossRef]

60. Rosini, E.F.; Tucci, A.; do Carmo, C.F.; Rojas, N.E.T.; de Barros, H.P.; Mallasen, M. Changes in phytoplankton spatial and temporal dynamics in a Brazilian tropical oligotrophic reservoir after net cage installation. Braz. J. Bot. 2016, 39, 569-581. [CrossRef]

61. Utermöhl, H. Zur Vervollkommnung der quantitativen Phytoplankton-Methodik. SIL Commun. 1958, 9, 1-38. [CrossRef] 
62. Fonseca, B.M.; Ferragut, C.; Tucci, A.; Crossetti, L.O.; Ferrari, F.; de Bicudo, D.C.; Sant'Anna, C.L.; de Bicudo, C.E.M. Biovolume de cianobactérias e algas de reservatórios tropicais do Brasil com diferentes estados tróficos. Hoehnea 2014, 41, 9-30. [CrossRef]

63. Hillebrand, H.; Dürselen, C.-D.; Kirschtel, D.; Pollingher, U.; Zohary, T. Biovolume calculation for pelagic and benthic microalgae. J. Phycol. 1999, 35, 403-424. [CrossRef]

64. World Health Organization. Guidelines for Safe Recreational Water Environments; WHO Library Cats Data; World Health Organization: Geneva, Switzerland, 2003; Volume 1, pp. 3505-3518.

65. Mihali, T.K.; Kellmann, R.; Muenchhoff, J.; Barrow, K.D.; Neilan, B.A. Characterization of the gene cluster responsible for cylindrospermopsin biosynthesis. Appl. Environ. Microbiol. 2008, 74, 716-722. [CrossRef]

66. Mihali, T.K.; Kellmann, R.; Neilan, B.A. Characterisation of the paralytic shellfish toxin biosynthesis gene clusters in Anabaena circinalis AWQC131C and Aphanizomenon sp. NH-5. BMC Biochem. 2009, 10, 8. [CrossRef]

67. Tillett, D.; Dittmann, E.; Erhard, M.; Von Döhren, H.; Börner, T.; Neilan, B.A. Structural organization of microcystin biosynthesis in Microcystis aeruginosa PCC7806: An integrated peptide-polyketide synthetase system. Chem. Biol. 2000, 7, 753-764. [CrossRef]

68. Dittmann, E.; Fewer, D.P.; Neilan, B.A. Cyanobacterial toxins: Biosynthetic routes and evolutionary roots. FEMS Microbiol. Rev. 2013, 37, 23-43. [CrossRef] [PubMed]

69. Mankiewicz-Boczek, J.; Izydorczyk, K.; Romanowska-Duda, Z.; Jurczak, T.; Stefaniak, K.; Kokocinski, M. Detection and monitoring toxigenicity of cyanobacteria by application of molecular methods. Environ. Toxicol. 2006, 21, 380-387. [CrossRef] [PubMed]

70. Rantala, A.; Rajaniemi-Wacklin, P.; Lyra, C.; Lepistö, L.; Rintala, J.; Mankiewicz-Boczek, J.; Sivonen, K. Detection of microcystin-producing cyanobacteria in Finnish lakes with genus-specific microcystin synthetase gene E (mcyE) PCR and associations with environmental factors. Appl. Environ. Microbiol. 2006, 72, 6101-6110. [CrossRef] [PubMed]

71. Kellmann, R.; Mihali, T.K.; Jeon, Y.J.; Pickford, R.; Pomati, F.; Neilan, B.A. Biosynthetic intermediate analysis and functional homology reveal a saxitoxin gene cluster in cyanobacteria. Appl. Environ. Microbiol. 2008, 74, 4044-4053. [CrossRef] [PubMed]

72. Bober, B.; Bialczyk, J. Determination of the toxicity of the freshwater cyanobacterium Woronichinia naegeliana (Unger) Elenkin. J. Appl. Phycol. 2017, 29, 1355-1362. [CrossRef]

73. Voloshko, L.; Kopecky, J.; Safronova, T.; Pljusch, A.; Titova, N.; Hrouzek, P.; Drabkova, V. Toxins and other bioactive compounds produced by cyanobacteria in Lake Ladoga. Est. J. Ecol. 2008, 57, 100-110. [CrossRef]

74. Willame, R.; Jurczak, T.; Iffly, J.-F.; Kull, T.; Meriluoto, J.; Hoffmann, L. Distribution of Hepatotoxic Cyanobacterial Blooms in Belgium and Luxembourg. Hydrobiologia 2005, 551, 99-117. [CrossRef]

75. Barboza, G.; Gorlach-Lira, K.; Sassi, C.; Sassi, R. Microcystins production and antibacterial activity of cyanobacterial strains of Synechocystis, Synechococcus and Romeria isolated from water and coral reef organisms of Brazilian coast. Rev. Biol. Trop. 2017, 65, 890-899. [CrossRef]

(C) 2020 by the authors. Licensee MDPI, Basel, Switzerland. This article is an open access article distributed under the terms and conditions of the Creative Commons Attribution (CC BY) license (http://creativecommons.org/licenses/by/4.0/). 